\title{
Outside-School Practice Base Construction Exploration For Logistics Management Professional Based On Training Mode 3+1
}

\author{
Liu Junqiang ${ }^{1, a}$ \\ ${ }^{1}$ No. 613, XiaoBa Road, Leshan City, Sichuan Province, China \\ a56777963@qq.com
}

Keywords: training mode $3+1$; logistics management; outside-school practice base.

Abstract. Practice teaching plays an important role in the application of Talents System. The off-campus training base is an important condition for the Practical Teaching. To strengthen Practicing Bases Construction is a strong guarantee for improving the quality of practice teaching and practical ability of students. The paper summarizes results Combined with implementation of off-campus practice bases of logistics management professional. It can provide reference for university practice base construction work.

In early 2009 the State Council promulgated the《logistics industry restructuring and revitalization plan 》. The logistics industry has become one of China's top ten industrial revitalization. Immediately afterwards the Ministry of Education issued the 《implementation of the logistics industry restructuring and revitalization plan, speed up the logistics personnel training work plan》. A series of policy tell us that state and industry needs logistics applications talents who can solve practical problems. This requires logistics management teaching should be based on the training of application talent and focus on improving the practical ability of logistics professionals.Practice teaching is an important part of the process to develop application-oriented talents for logistics professionals.

The off-campus practice base is the important places for cultivating students' practical ability and creativity. Further constructing the practice bases and helping students to acquire practical working knowledge through taking advantage of such out-of-campus bases. We have established the stable practice bases outside school to facilitate the practical teaching.

\section{Significance of outside-school practice base construction}

In recent years, with the expansion of the scale of graduates of logistics, the problem of employment for logistics majors is increasingly prominent. At the same time, due to the logistics is a sector with a strong practical requirements and companies need to recruit employees with a strong practical ability, which enable enterprises especially difficult to recruit people. In order to develop logistics professionals applied talents we must vigorously strengthen the practice of teaching and effectively improve students' comprehensive practical ability. Quality of practice teaching determines the quality of logistics personnel. The off-campus practice base is the important places for cultivating students' practical ability and creativity. Many colleges and universities take the practice teaching methods of the combination of the campus internship and off-campus internship. School internship uses of simulation software to carry out the practice of teaching and it improve the students' ability to apply to a certain extent. But simulation content is a gap with real situation of industry. The off-campus internships allow students to contact with the actual production and master production skills before entering the society because of practice is carried out in real enterprises. Strengthen the construction of practice bases has become one of the most important step. The level of practice bases construction determines the development of the logistics discipline. Integrated use of social education resources and build training base is the key to highlight the school characteristics and improve the quality of the logistics personnel training.

Practice bases construction can strengthen cooperation between schools and businesses, and to promote research cooperation. And also it not only can Improve students' practical ability and promote 
employment of graduates, but also can enhance teachers' practical ability. And it has an important influence on the professional development of discipline, the Revision of teaching programs, programs teaching reform and the development of students' ability for work.

\section{Implementation of outside-school practice base construction}

Election of outside-school practice base

Outside-school practice base construction should be with a win-win and to jointly promote for the principle. Only a balanced on the interests of both and mutually benefit can form a long-term stable cooperative relations and realize a win-win situation. Only a certain number of long-term and stable practice base in order to provide long-term opportunities for students to practice, so as to ensure the quality of internships.

Outside-school practice base construction should be student-centered and do teaching goals in the first place. Whether the training base will be able to meet internship requirements prescribed by training program is an important criterion for Outside-school practice base construction. So it is important to choose a representative, industry-leading logistics enterprises to cooperate to establish training base in logistics-related areas of expertise. Geographical distribution and job situation of the cooperative units should be conducive to co-ordinate and manage for the construction of practice base.

Logistics management currently has built training bases with a number of logistics enterprises at home and abroad. Partners include foreign companies, joint ventures, state-owned enterprises and private enterprises. Cooperation in the field of business units, including logistics, express, express and international freight forwarding and other mainstream logistics fields can meet the students' job requirements. The geographical distribution of co-operation including Guangzhou, Shanghai, Hangzhou and Chengdu can meet the student's different requirements for expertise to the developed areas.

Implementation of Outside-school Practice Base Construction

The first is the implementation of " $3+1$ " training mode. $3+1$ Training model has a good practical foundation. At present different types of colleges and universities explore different training model around the characteristics of its own conditions. The $3+1$ training mode fumble in teaching by logistics management of The Engineering Technical College of Chengdu University of Technology is an undergraduate applied talents training mode employment-oriented which take all-round development of students and adapt to the social economic development as the goal and application-oriented capacity-building as the core and the depth of cooperation between schools and enterprises as a means. Its operating mode is that the students do the major theoretical and practical learning at the school three years and enter cooperative enterprises to internship in the fourth year. Logistics management currently has built training bases with a number of logistics enterprises at home and abroad and it has sent many group of students into cooperative units to internship.

The second is to strengthen the construction of trainee teachers, implementation of dual tutorial. Internship guidance requires an experienced, strong sense of responsibility of teachers. In practice team building, logistics management is not only to encourage the profession teachers to enter cooperation with testing and training to improve practical ability, but also support for cooperative enterprises regularly sent practice instructor to the colleges to theoretical training to strengthen theoretical guidance to the students. And also put it as a long-term strategy to improve the knowledge structure of teachers that introduction of senior technical talent teachers who having a business background. In addition, in the aspect of practice guidance, the double mentoring system is implemented that the students are guided by the enterprise engineers and school teachers in order to jointly develop students' comprehensive ability.

The third is conduct enterprises internships for students. Enterprises internship provide a real business environment for students and it can improve professional quality and professional ability for logistics students. It can not only improve the students 'skill levels, enhance the students' awareness of their own positions, but also define the future direction of employment and Realize seamless from 
school to business. Conduct enterprises internships, reduce labor costs, indirect increase enterprise efficiency, but also effectively improve students' comprehensive ability by means of enterprise platform to for schools.

The fourth is to expand the vocational training business based on the regional economic construction and social development. Actively expand social services in virtue of practice bases and provide training and technical support for logistics employees and business transformation and technological innovation are good ideas to share existing resources. And the measures can make off-campus practice base to become applied logistics personnel training base and service window.

\section{Results on practice base outside school}

The first is to increase the students' professional skills and professional quality. Logistics students participate in all aspects of business management in his capacity of employees in off-campus practice base for enterprises internships. Such practice will help students gain practical work experience, think the development of the industry, feel the corporate culture, cultivate good professional quality and comprehensive practical ability and broaden the student employment channels.

The second is to promote improving on practice teaching quality. Construction and development on practice bases in favor of resource construction and development of professional practice teaching, promoted to enhance the quality of practice teaching, and promote high-quality curriculum construction. And also Logistics majors gradually learn to use the theory to solve practical problems encountered in the work. Through in-depth cooperation, the two sides involved in cultivating applied logistics personnel about the two sides build personnel training programs, build curriculum and build teachers team.

The third is comprehensive research cooperation with enterprises and closer relationship between schools and enterprises.

Through the effective operation of practice bases, logistics teachers and enterprises are more closely than before. Scope for further is enlarged on cooperation between schools and enterprises. And also it provides better conditions for logistics personnel training.

\section{References}

[ 1 ] Yang Yanqiu , Li Weikai . Innovative Research On Training Base Building Mechanisms And Practice Teaching Model for Local colleges [ J ] . Heilongjiang Researches on Higher Education , 2012 , (7) : $157 \sim 160$

[ 2 ] Wang Juan . On Strengthening the Construction of Undergraduate Practice Base Thinking [ J ] . Journal of Fujian Normal University (Natural Science Edition), 2011, (5) : 90 93

[ 3 ] Ye Chong, Wang Mengyu. Practice Teaching Base Construction of Logistics Professional Based on Push and Pull Factors [ J ] . Logistics Engineering and Management , 2015 , (11) : 279 281

[ 4 ] Xia Hailan, Zhang Wenlu . Construction of Off-campus Practice Bases Based on Deep

Cooperation between Universities and Enterprises [ J ] . Research and Exploration in Laboratory, $2013,(8): 439 \sim 442$

[ 5 ] Dong Jianwen. Study on Practice of Construction of University Logistics Specialty in New Situation [J]. Logistics Technology , 2013 , ( 8 ) 
[ 6 ] Xie Ruhe. Professional norms and Characteristics Construction for logistics management based on "Engineering - management integration" [J]. Research in Higher Education of Engineering , 2015 , ( 3 ) 